\title{
Chemerinin Sağlık Üzerine Etkisi
}

\section{The Effect of Chemerin on Health}

Fatmanur Hümeyra Zengin ${ }^{1}$, Efsun Karabudak ${ }^{1}$,

${ }^{1}$ Sağlık Bakanlığı, SBÜ Ankara Eğitim ve Araştırma Hastanesi, Beslenme ve Diyet Bölümü, Ankara, Türkiye

${ }^{2}$ Sanko Üniversitesi, Sağlık Bilimleri

Fakültesi, Beslenme ve Diyetetik Bölümü, Gaziantep, Türkiye

Geliş Tarihi/Received: 26 Şubat 2020

Kabul Tarihi/Accepted: 24 Temmuz 2020

Yazışma Adresi: Fatmanur Hümeyra Zengin, Sağlık Bakanlığı, SBÜ Ankara Eğitim ve Araştırma Hastanesi, Beslenme ve Diyet Bölümü, Ankara, Türkiye

e mail: humeyrazengin@hotmail.com

\section{ORCID}

Fatmanur Hümeyra Zengin

https://orcid.org/0000-0003-1586-5878

Efsun Karabudak

https://orcid.org/0000-0002-4210-1657

\begin{abstract}
Öz
Adipoz dokunun sadece pasif bir enerji deposu değil, aynı zamanda endokrin bir organ olduğunun anlaşılması ile salgıladığı biyoaktif faktörlere ilgi artmıştır. Adipositlerin yanı sıra pre-adipositler, makrofajlar, endotel hücreler, fibroblastlar ve lökositlerden oluşan adipoz doku, sistemik metabolik regülasyonda önemli bir role sahiptir. Tazaroten ile indüklenen gen 2 (TIG2) veya retinoik asit reseptör cevaplayıcı 2 (RARRES2) olarak adlandırılan chemerin ilk olarak 1997'de psoriatik cilt lezyonlarında, retinoik aside duyarlı bir gen olarak keşfedilmiştir. Daha sonra chemerin'in, adiposit farklılaşmasını, glukoz ve lipit metabolizmasında önemli genlerin ekspresyonunu değiştirdiğini gösteren verilerle adipogenezi ve adiposit metabolizmasını düzenlediği belirlenmiş ve yeni bir adipokin olarak sınıflandırılmıştır. Chemerin dolaşımda ve inflamatuvar sıvılarda etkilerine reseptörü G protein-bağlı reseptör kemokin benzeri reseptör 1 (CMKLR1) yoluyla aracılık etmektedir. Obezite, metabolik sendrom (MetS), tip 2 diyabet (T2DM), polikistik over sendromundan (PKOS) inflamatuvar hastalıklara kadar çeşitli hastalıklarda lokal ve/veya dolaşımdaki chemerin seviyelerinin artması ile ilişkili klinik araştırmaların sayısındaki artış chemerinin bu hastalıkların patogenezindeki önemli rollerini desteklemektedir. Her ne kadar bu hastalıklarda serum chemerin seviyelerinin yükseldiği açık olsa da, chemerin ekspresyonunu düzenleyen mekanizmalar tam olarak anlaşılamamıştır. Chemerinin etki mekanizmalarının anlaşılabilmesi için daha fazla randomize kontrollü çalışmaya intiyaç duyulmaktadır.
\end{abstract}

Anahtar Kelimeler: Chemerin, adipoz doku, adipogenez, inflamasyon, insülin direnci

\section{Abstract}

With the understanding that adipose tissue is not only a passive energy store, but also an endocrine organ, interest in bioactive factors secreted from adipose tissue has increased. Adipose tissue, consisting of pre-adipocytes, macrophages, endothelial cells, fibroblasts and leukocytes, as well as adipocytes, has an important role in systemic metabolic regulation. Chemerin, called tazarotene-induced gene 2 (TIG2) or retinoic acid receptor responder 2 (RARRES2), was first discovered in 1997 in psoriatic skin lesions as a retinoic acid-sensitive gene. It was later determined that chemerin regulates adipogenesis and adipocyte metabolism, with data showing that it alters adipocyte differentiation, expression of important genes in glucose and lipid metabolism, and is classified as a new adipokine. The effects of chemerin in circulating and inflammatory fluids are mediated through receptor $\mathrm{G}$ protein-bound receptor chemokine-like receptor 1 (CMKLR1). The increase in the number of clinical trials associated with increased levels of local and I or circulating chemerin in various diseases, from obesity, metabolic syndrome (MetS), type 2 diabetes mellitus (T2DM), polycystic ovarian syndrome (PCOS) to inflammatory diseases, supports the important roles of chemerin in the pathogenesis of these diseases. Although it is clear that serum chemerin levels increase in these diseases, the mechanisms regulating the expression of the chemerin are not fully understood. More randomized controlled studies are needed to understand the mechanisms of action of chemerin.

Key words: Chemerin, adipose tissue, adipogenesis, inflammation, insulin resistance
Atıf yapmak için: Zengin FH, Karabudak E. Chemerinin Sağılı Üzerine Etkisi. Selcuk Med J 2021;37(1):83-89
Açıklama: Yazarların hiçbiri, bu makalede bahsedilen herhangi bir ürün, aygıt veya ilaç ile ilgili maddi çıkar ilişkisine sahip değildir. Araştırma, herhangi bir dış organizasyon tarafından desteklenmedi. Yazarlar çalışmanın birincil verilerine tam erişim izni vermek ve derginin talep ettiği takdirde verileri incelemesine izin vermeyi kabul etmektedirler. 


\section{GíRIŞ}

Son yirmi yılda adipoz doku kaynaklı biyoaktif faktörler ile bunların fizyolojik işlevlerini anlamak için yoğun çaba sarf edilmiş ve adipoz dokunun sadece pasif bir enerji deposu değil, aynı zamanda endokrin bir organ olduğu anlaşılmıştır (1). Adipoz doku etkilerini hem lokal (otokrin / parakrin) hem de sistemik (endokrin) bir şekilde gerçekleştirir. Adipositlerin yanı sıra pre-adipositler, makrofajlar, endotel hücreler, fibroblastlar ve lökositlerden oluşan adipoz doku, sistemik metabolik regülasyonun önemli bir oyuncusudur (2). Adipoz dokudan salgılanan biyoaktif faktörler endokrin mekanizmalar yoluyla kas, karaciğer, pankreas ve beyin gibi diğer metabolik olarak aktif organlara aktarılmakta, böylece sistemik metabolizmayı modüle etmektedir. Adipokinler etkilerini; hedef hücrelerin zarındaki ilgili reseptörlere bağlanarak ve belirli hücre içi sinyal yollarının tetiklenmesi aracılığı ile yapmaktadırlar (3). Adipokinlerin biyosentezinin, salgılanmasının ve sinyal iletiminin bozulması özellikle obezite ve ilişkili bozuklukların gelişimi ile ilişkilidir (4). Son zamanlarda keşfedilen chemerin, adipokinlerin farklılaşmasını sağladığı ve glukoz uptake'inde görev aldığı için yeni bir adipokin olarak sınıflandırılmaktadır (5). Çalışmalar chemerinin, reseptörü $G$ protein-bağlı reseptör kemokin benzeri reseptör 1 (CMKLR1) aracılığıyla adipoz dokuda adipogenezi, anjiyogenezi ve inflamasyonu etkilediğini göstermektedir $(6,7)$. Obezite, metabolik sendrom (MetS) ve tip 2 diyabetten (T2DM) inflamatuvar hastalıklara kadar çeşitli hastalıklarda lokal ve / veya dolaşımdaki chemerin seviyelerinin artması ile ilişkili klinik araştırmaların sayısındaki artış chemerinin bu hastalıkların patogenezindeki önemli rollerini desteklemektedir (810). Bu derlemede bir adipokin olan chemerinin sağlık üzerine olası etkileri üzerinde durulacaktır.

\section{Chemerin}

Başlangıçta tazaroten ile indüklenen gen 2 (TIG2) veya retinoik asit reseptör cevaplayıc 2 (RARRES2) olarak adlandırılan chemerin ilk olarak 1997'de psoriatik cilt lezyonlarında retinoik aside duyarlı bir gen olarak keşfedilmiştir (11). Keşfinden sonra biyolojik fonksiyonu, insan inflamatuvar sıvılarında saptanana kadarki süreçte belirsizliğini korumuştur. Chemerin 2003 yılında, proteolitik aktivasyon gerektiren ve antijen sunan hücrelere (APC) özgü yeni, güçlü bir kemoatraktan protein olarak tanımlanmıştır (6). Dört yıl sonra da, chemerin'in, adiposit farklılaşmasını, glukoz ve lipit metabolizmasında önemli genlerin ekspresyonunu değiştirdiğini gösteren verilerle adipogenezi ve adiposit metabolizmasını düzenlediği belirlenmiş ve yeni bir adipokin olarak sınıflandırılmıştır $(5,12)$.

\section{Chemerinin Yapısı}

Memeli hücrelerinde chemerin başlangıçta 163 amino asitten (aa) oluşan pre-prochemerin olarak sentezlenmektedir. Pre-prochemerin, $\mathrm{N}$-terminal prosesine tabi tutularak $18 \mathrm{kDa}$ (163 amino asit) molekül ağırlığındaki inaktif protein olan prochemerine (chemerinS163) dönüştürülmektedir (13-15). Prochemerin henüz belirlenemeyen bir mekanizmayla $\mathrm{N}$-terminal prosesi ile koagülasyon, fibrinolitik veya inflamatuvar kaskadın hücre dışı proteazları tarafından C-terminalinde bölünme gerçekleşir ve chemerinin aktif 16 kDa formları üretilir (16). Biyoaktif chemerinin kimaz tarafından daha fazla bölünmesi ile chemerinF154 üretilir ve aktivitesi sonlanır (17) (Şekil 1). C-terminal proteolitik prosesi, aktif chemerinin lokal ve sistemik konsantrasyonunu belirlemek için anahtar bir düzenleyici mekanizma görevi görmektedir. Bugüne kadar, in vitro ortamda C-terminal olarak chemerin ve prekürsörünün işlenmesi için sekiz serin proteazı tanımlanmıştır. $\mathrm{Bu}$ serin proteazlar genel olarak biyolojik etkilerini sergilemek için hücre dışı matris veya kan plazmasına salgılanırlar (17). Örneğin, C-terminalindeki plazmin, elastaz ve katepsin G ile proteolitik bölünme sonucu chemerin aktif olur ve çeşitli izoformlar üretir. İlginç bir şekilde, C-terminal bölünmesinin kapsamı, chemerinin bulunduğu yere göre değişmektedir (15). In vitro rekombinant insan chemerin çalışmalarında; insan kanında (chemerinA155, -S157 ve -K158),

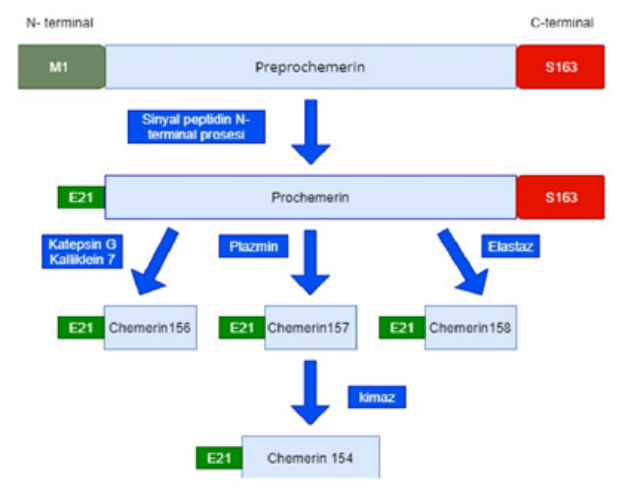

Şekil. Chemerinin aktif formlarının sentez süresi (17) 
beyin omurilik sıvısında (chemerinK158), karın için sıvida (chemerin-S157), hemofiltratta (chemerin -F154) ve inflamatuvar koşullar altında sinovyal sıvı da (chemerinK158) farklı chemerin izoformları tespit edilmiştir $(13,15,18)$. Chemerin izoformlarından chemerin G152, chemerin F154 ve chemerin A155 inaktiftir veya çok düşük biyolojik aktiviteye sahiptir. Chemerin K158 düşük aktiviteye, chemerin F156 orta derecede yüksek aktiviteye ve chemerin $\mathrm{S157}$ ise en yüksek biyolojik aktiviteye sahiptir (16). Sağlıklı, normal vücut ağırlığındaki bireylerde, toplam chemerin konsantrasyonu hem serumda hem de plazmada 90 ile $200 \mathrm{ng} / \mathrm{mL}$ arasında değişmektedir $(19,20)$.

\section{Chemerinin Reseptörleri}

Kemoatraktan bir protein olan chemerin, etkili olabilmek için reseptörlere ihtiyaç duyar ve bilinen üç reseptörü vardır. ChemR23 olarak da bilinen CMKLR1, anjiyogenez ve inflamasyon gibi biyolojik fonksiyonları düzenleyen ve şimdiye kadar sinyal aktivitesi tespit edilen iki chemerin reseptöründen biridir $(6,17,21)$. İkincisi, G protein-bağlı reseptör 1'dir (GPR1) (22). Üçüncü chemerin reseptörü olan kemokin reseptörü benzeri 2 (CCRL2) ise, büyük olasılıkla herhangi bir sinyal aktivitesi göstermeyen atipik bir kemokin reseptörüdür $(23,24)$. Chemerin dolaşımda ve inflamatuvar sıvılarda etkilerine CMKLR1 yoluyla aracılık etmekle birlikte aktif chemerin izoformlarının her biri CMKLR1'e farklı afinetelerle bağlanmaktadır (16). Diğer iki reseptör olan GPR1 ve CCRL2'nin de chemerini bağladığı gösterilmiştir, ancak bu chemerin reseptörlerinin farmakoloji ve sinyal özellikleri hakkında daha az bilgi vardır. Chemerin üç reseptöre de yüksek afiniteli bağlandığı gösterilmiş, ancak hem CMKLR1 hem de GPR1 daha yüksek afinite (24) ile CCRL2 ise en düşük afinite ile bağlanmıştır (25).

\section{Chemerinin Ekspresyonu ve Salgılanması}

Chemerin, karaciğerde, adipoz dokuda (beyaz adipoz dokuda, kahverengi adipoz dokuya kıyasla daha yüksek seviyelerde) ve plasentada yüksek seviyelerde eksprese edilirken, aynı zamanda ciltte, immün sistemde (makrofajlarda, doğal öldürücü hücrelerde, olgunlaşmamış dendritik hücrelerde ve lökositlerde), üreme sisteminde, adrenal bezde, bağırsakta, pankreasta, solunum yollarında ve böbreklerde de az miktarda ekspre edilmektedir $(5,12,17)$. Reseptör CMKLR1'de özellikle lökositlerde makrofajlarda, olgunlaşmamış dendritik hücrelerde ve beyaz yağ dokusunda yüksek oranda eksprese edilirken iskelet kası (26), kemik, akciğer, beyin (17), kalp, overler ve plasentada daha düşük seviyelerde eksprese edilmektedir $(6,12)$. GPR1, CMKLR1 ile yakından ilişkilidir, ancak GPR1 lökositlerde ekspre edilmemekte, ağırlıklı olarak glioblastoma hücreleri, beyinden türetilmiş fibroblast benzeri hücre çizgileri ve mikroglia gibi merkezi sinir sisteminde ekspre edilmektedir. Bununla birlikte, cilt hücrelerinde, beyaz adipositlerde, Leydig hücrelerinde ve granülosa hücrelerinde ekspresyonu bildirilmiştir $(12,18)$. CCLR2 ise, büyük ölçüde adipoz dokuda yoktur, in vivo olarak akciğer endotel hücrelerinde yüksek ve karaciğer endotelinde, kalp, dalak ve lökositlerde düşük seviyelerde ekspre edildiği görülmüştür (12, 23).

\section{Chemerinin Sağlık Üzerine Etkisi}

Chemerin ve reseptörlerinin dahil olduğu mekanizmalar büyük ölçüde bilinmemekle birlikte in vivo olarak otokrin, parakrin ve hatta endokrin rolleri olan adipokinler arasında tanımlanmıştır. Chemerinin otokrin yanıtı; lipoliz, glukoz alımı ve lipostatik sinyalizasyonu düzenleyen metabolik yolaklarla bağlantılıdır. Parakrin yanıtı ise; obezite ile ilişkili kronik düşük dereceli inflamasyon boyunca aktif olmasıdır (12). Chemerinin, adipositlerin farklılaşmasını düzenlediği, adipogenez, osteoklastogenez, anjiyogenez, cilt ve adipoz dokuda inflamatuvar süreçlerde rol oynadığı; serum chemerin seviyesinin beden kütle indeksi (BKI), serum trigliserit düzeyi, insülin direncinin homeostatik model değerlendirmesi (HOMA-IR) ve kan basıncı ile ilişkili olduğu çalışmalarda gösterilmiştir $(5,13)$.

\section{Inflamasyon}

Chemerin normalde sağlıklı bireylerin dolaşımında bulunmakla birlikte inflamasyonlu dokularda ve sıvılarda, ülseratif kolit ve crohn hastalığı gibi kronik inflamatuvar hastalıklarda seviyesinin arttığı gösterilmiştir (27). Vermi et al. (8) çalışmalarında Lupus eritematöz deri lezyonlarında, dermal kan damarlarının endotelinde ve sekonder lenfoid organların yüksek endotel venlerinde immünohistokimya ile chemerin tespit etmişlerdir. Enfeksiyona karşı konakçı savunma, bağışıklık sisteminin hem doğal hem de adaptif kollarının entegre bir tepkisini gerektirmektedir. Doğuştan gelen ve adaptif immünite arasındaki geçitte, istilacı patojenlere karşı immün yanıtların başlatılmasında ve düzenlenmesinde anahtar rol oynayan profesyonel APC olan dendritik hücreler vardır (28). Chemerin, reseptörü CMKLR1 ile birlikte olgunlaşmamış dendritik hücrelerin ve makrofajların kemotaksisini teşvik etmekte ve hasarlı bölgeye immün hücrelerin toplanmasını sağlayarak kemoatraktan bir rol oynamaktadır $(6,12)$. Wittamer et al. (28) yaptığı çalışma; biyoaktif chemerin oluşumunun 
inflamasyonun erken evrelerinde gerçekleştiği ve bu durumun chemerinin doğuştan ve adaptif bağışıklık arasında bir köprü olarak işlevsel katkısı olduğunu göstermektedirler. İnflamatuvar koşullarda üretilen ve doğuştan gelen immün yanıtlarda rol oynayan hücreleri etkiyen kemoatraktan bir faktör olarak, chemerinin başlangıçta bir proinflamatuvar ajan olarak davrandığı bildirilmişti (29). Son veriler ise araştırılan hastalık modeline göre ya proinflamatuvar ya da antiinflamatuvar olan daha karmaşık aktivitelere işaret etmektedir (30-32). İnflamatuvar reaksiyonun başlangıcında, polimorfonükleer hücreler ilk önce hasarlı bölgelerde toplanır, burada elastaz ve katepsin $\mathrm{G}$ içeren proteazları ortama bırakarak biyolojik olarak aktif chemerin oluşumunu teşvik ederler. Daha sonra chemerin, olgunlaşmamış dendritik hücrelerin ve makrofajların kemotaksisini güçlendirir, immün yanıtın başlatılması için doğal ve adaptif immünite arasında köprü oluşturur (6). Chemerin tedavisi ise bunun tersine nötrofil ve makrofajların inflamasyonlu bölgelere alınmasını ve proinflamatuvar sitokin ekspresyonunu azaltır (32). Yapılan bir çalışmada hava yollarının sigara dumanına akut veya kronik olarak maruz bırakılmasının ardından farelerinin bronkoalveolar lavaj (BAL) sıvısında, chemerin seviyelerinin arttığını belirlemişlerdir. Proinflamatuvar kemokinler CXCL1, -CCL2 ve -CCL20, sigara dumanına maruz kalan farelerinin solunum yollarında, inflamatuvar nötrofiller ve monositler, dendritik hücreler ve $\mathrm{T}$ hücrelerinin büyük bir birikimi ile birlikte artmıştır (31). Bu gözlemler, chemerinin doğuştan gelen ve adaptif immün hücrelerin sigara dumanına maruz kalmış akciğerlere alınmasına önemli ölçüde katkıda bulunduğunu ve bu bağlamda proinflamatuvar bir rol oynadığını göstermektedir (31). Yapılan çalışmalarda serum chemerin düzeyleri, proinflamatuvar sitokin tümör nekroz faktörü (TNF)- $\alpha$, interlökin (IL)-6 ve C reaktif protein (CRP) düzeyleri ile korele olduğu gösterilmiştir $(27,34)$. Buna karşılık, Cash et al. (32) yaptıkları bir çalışmada chemerinCMKLR1 sisteminin antiinflamatuvar özelliklerini tanımlamıştır. Farelerde zymosan kaynaklı peritonit modelinde chemerin ve chemerin türevli peptitlerin ex vivo makrofajlar üzerindeki etkisi araştırılmış, chemerin ve chemerin türevli peptit C15 CMKLR1 aracılığı ile antiinflamatuvar aktiviteler göstermiş ve proinflamatuvar mediatör ekspresyonunda eşzamanlı bir azalma ile nötrofil (\%63) ve monosit (\%62) alımını baskılayarak zymosan kaynaklı peritonite karşı önemli bir koruma sağlamıştır.

\section{Obezite}

Chemerinin 2007 yılında beyaz adipoz dokuda yüksek oranda ekspre edildiğinin bulunması ile sadece bağışıklık sisteminde etkili olmadığı anlaşılmıştır. Chemerin anjiyogenez, adipogenez ve enerji metabolizmasını düzenleyen bir adipokindir (12). Obezite hastalarının adipoz dokusunda chemerin izoformları, minimum chemerin prekürsörü ve belirgin biyoaktif chemerinS157 seviyeleri ile plazmadan farklı bir durum sergilemektedir (17). Çalışmalarda, chemerin seviyesinin $\mathrm{BKI}$, total vücut yağ yüzdesi ve bel çevresi ile pozitif olarak ilişkili olduğu gösterilmiştir $(34,35)$. 1431 Meksikalı üzerinde yapılan bir çalışmada, zayıf kontrollerle ile karşılaştırıldığında, obez ve fazla kilolu bireylerde anlamlı derecede daha yüksek serum chemerin seviyeleri rapor edilmiştir (20). Fareler üzerinde yapılan bir çalışmada chemerinin anjiyogenezi uyardığı görülmüştür (36). Daha sonra chemerin'in anjiyogeneze neden olduğu mekanizmalar araştırıldığında, chemerin insan göbek ven endotel hücrelerinin (HUVEC) kılcal benzeri yapılara farklılaşmasını uyarmış, HUVEC'lerin çoğalmasını desteklemiş ve göç deneylerinde kemoatraktan bir madde olarak işlev görmüştür. Chemerin, HUVEC'lerde Akt ve p42 / 44 hücre dışı sinyal düzenlenmiş kinazın (ERK) fosforilasyonunu indüklemiş ve chemerin, Akt ve ERK yoluyla anjiyogenezi teşvik etmiştir (36). Böylece adipogenez sırasında chemerin yüksek ekspresyonu ve salgılanması, anjiyojenezi indükleyerek ve adipoz doku vaskülarizasyonunu artırarak adipoz doku büyümesini de destekleyebileceği gösterilmiştir (15). Adipogenesis ile de chemerin ekspresyonu ve salgılanması yükselmiştir (35). Her ne kadar obezitede serum chemerin seviyelerinin yükseldiği açık olsa da, chemerin ekspresyonunu düzenleyen mekanizmalar tam olarak anlaşılamamıştır.

\section{Insülin Direnci, Tip 2 Diyabet}

İnsülin direnci ve subklinik inflamasyon, T2DM'nin gelişimindeki özelliklerdendir. Bir adipokin olan chemerin her iki faktörle de ilişkilendirilmiştir. Chemerinin in vitro ve hayvan çalışmalarında hem adipositlerde hem de iskelet kasında insülin direncini de içeren insülin sinyalizasyonunu ve glukoz atılımını modüle ettiği gösterilmiştir $(37,38)$. Chemerinin T2DM'yi öngörüp öngörmediğini analiz etmek için Metabolik Sendrom Berlin-Potsdam (MesyBepo) takip çalışmasına dahil edilen 440 katılımcının (diyabeti olmayan) kan örneklerinde chemerin çalışılmıştır. Katılımcıların ortalama takip süresi 5,3 yıl olup izlem sırasında 33 bireyde T2DM gelişmiştir. Yaş, cinsiyet, BKI, bel çevresi istatistiksel olarak 
düzenlendikten sonra chemerin seviyesi arttıkça T2DM görülme intimalinin arttığı görülmüştür (39). Habib et al. (40) yaptığı çalışmada serum chemerin düzeyleri diyabetlilerde kontrollere göre daha yüksek bulunmuştur. Chemerin düzeyleri yaş, bel/kalça oranı, vücut ağırlığı, BKİ, vücut yağ yüzdesi, yağ kütlesi, visseral yağ, serum bazal insülin seviyeleri ve HOMA IR ile pozitif bir korelasyon göstermiştir. Çoklu lineer regresyon analiz sonucunda yaş, vücut yağ yüzdesi ve bazal insülin düzeyleri chemerinin bağımsız prediktörleri olduğu görülmüştür.

\section{Metabolik sendrom}

Metabolik sendrom (MetS), glukoz intoleransı, obezite, hipertansiyon ve dislipidemi ile karakterize yaygın bir metabolik bozukluktur. Patofizyoloji, büyük ölçüde aşırı yağ birikimi ile insülin direncine atfedilebilir gibi görünmekle birlikte proinflamatuar bir durum sendroma katkıda bulunur (41). Chemerinin, MetS parametreleri ile ilişkisinin incelendiği bir çalışmada; chemerin hem kesitsel hem de boyuna analizlerde abdominal yağ birikimi ve MetS parametreleri ile ilişkili bulunmuştur (42). Esansiyel hipertansif bireylerin sağlıklı kontrollerle chemerin seviyelerinin karşılaştırıldığı bir çalışmada, hipertansif bireylerde serum chemerin düzeyleri anlamlı derecede yüksek bulunmuştur. Chemerinin, hipertansif kişilerde yaş ve cinsiyetten bağımsız olarak inflamasyon belirteçleri (yüksek duyarlıklı CRP, TNF- $\alpha$ ve IL-6) ve MetS bileşenleri (BKI, sistolik kan basıncı, açlık glukozu ve insülin, trigliserit, total kolesterol, HOMA-IR) ile güçlü bir şekilde ilişkili olduğu rapor edilmiştir (43). Çin Han popülasyonunda MetS'liler chemerin seviyelerinin ve metabolik sendrom bileşenleri (BKI, kan basıncı, kan lipitleri ve kan şekeri) ile olan ilişkisini araştırıldığı bir çalışmada; chemerin düzeyinin MetS grubunda kontrol grubuna göre daha yüksek olduğu ve chemerin seviyesinin sistolik kan basıncı, bel çevresi, BKI, bel -kalça oranı, açlık kan şekeri ve açlık insülini ile pozitif korelasyon gösterdiği bulunmuştur. Bununla birlikte, yüksek yoğunluklu lipoprotein kolesterol ile negatif korelasyon göstermiştir (44).

\section{Polikistik over sendromu}

Polikistik over sendromu (PKOS), menstrüel düzensizlik, infertilite, hirşutizm ve akneye neden olabilen hiperandroizm ve MetS, T2DM $(45,46)$, inflamasyon (47), kardiyovasküler (KVH) ve psikolojik (48) hastalıklarla ilişkilendirilen bir sendromdur (49). PKOS'lu kadınların serum chemerin seviyelerinin sağlıklı bireylerle karşılaştırıldığı çalışmalarda PKOS'lu kadınların serum chemerin seviyeleri kontrol grubundan daha yüksek çıkmıştır $(50,51)$. Kort et al. (52) yaptıkları çalışmada obeziteden bağımsız olarak, chemerin ve PKOS arasında bir korelasyonun varlığı tespit edilmekle birlikte PKOS'lu kadınlarda chemerinin, BKI, abdominal obezite ve insülin direnci ile korelasyon gösterdiği rapor edilmiştir. Chemerinin, yağ dokusunda kemoatraktan bir madde olarak inflamatuvar rolü sayesinde PKOS'ta insülin direncinin önemli bir belirleyicisi olabileceği sonucuna varılmıştır (52). Yapılan bir başka çalışmada ise, PKOS'lu kadınlarda foliküler sıvıda ve granulosa hücrelerinde chemerin konsantrasyonu ve reseptörlerinin mRNA ekspresyonu, PKOS olmayanlardan daha yüksek bulunmuştur. Foliküler sıvıda chemerinin, total testosteron (TT) ve luteinize edici hormon (LH) ile pozitif olarak korele olduğu görülmüştür. Over hiperandrojenizme neden olabilen PKOS hastalarının yumurtalıklarındaki yükselen chemerin seviyeleri oosit olgunlaşması ve embriyo gelişimi için risk faktörü olabileceği sonucuna varılmıştır (53).

\section{SONUÇ}

Adipoz dokunun sadece vücudun ana enerji deposu olmadığının anlaşılması adipokinlere ilgiyi giderek arttırmıştır ve artırmaktadır. Dolaşımdaki adipokin seviyelerinin artan adipozite ile değiştiği ve bu nedenle obezite ile ilişkili görülen metabolik bozukluklardaki değişikliklere katkıda bulunan bir faktör olduğu düşünülmektedir. Chemerin obezite, inflamasyon ve insülin direnci ile ilişkili olduğu belirlenen yeni bir adipokindir. Son yıllarda yapılan çalışmalarda; obezite, MetS, T2DM, PKOS gibi obezite ile ilişkili çeşitli hastalıklarda lokal ve/veya dolaşımdaki chemerin seviyelerinin sağlıklı bireylere göre yüksek bulunması bu hastalıkların patogenezinde chemerinin önemli bir rolü olduğunu göstermektedir. Chemerinin etki mekanizmalarının anlaşılabilmesi için daha fazla randomize kontrollü çalışmaya intiyaç duyulmaktadır.

Çıkar Çatışması: Çalışmada herhangi bir çıkar çatışması yoktur.

Finansal Çıkar Çatışması: Çalışmada herhangi bir finansal çıkar çatışması yoktur.

Yazışma Adresi: Fatmanur Hümeyra Zengin, Sağlık Bakanlığı, SBÜ Ankara Eğitim ve Araştırma Hastanesi -Beslenme ve Diyet Bölümü, Sakarya Mah. Ulucanlar cad. No:89 Altındağ, Ankara, Türkiye

Telefon: (506) 4462286

e-mail: naksoy44@yahoo.com

\section{KAYNAKLAR}

1. Raucci R, Rusolo F, Sharma A, et al. Functional and structural features of adipokine family. Cytokine 2013;61(1):1-14. 
2. Kershaw EE, Flier JS. Adipose tissue as an endocrine organ. J Clin Endocrinol Metab 2004;89:2548-56.

3. Luo L, Liu M. Adipose tissue in control of metabolism. J Endocrinol 2016;231(3):R77-99.

4. El Husseny MW, Mamdouh M, Shaban S, et al. Adipokines: Potential therapeutic targets for vascular dysfunction in type II diabetes mellitus and obesity. J Diabetes Res 2017:8095926.

5. Bozaoglu K, Bolton K, McMillan J, et al. Chemerin is a novel adipokine associated with obesity and metabolic syndrome. Endocrinology 2007;148(10):4687-94.

6. Wittamer V, Franssen JD, Vulcano $M$, et al. Specific recruitment of antigen-presenting cells by chemerin, a novel processed ligand from human inflammatory fluids. J Exp MedRevie 2003;198(7):977-85.

7. Yang X, Yao J, Wei Q, et al. Role of chemerin/CMKLR1 in the maintenance of early pregnancy. Front Med 2018;12(5):52532.

8. Vermi W, Riboldi E, Wittamer V, et al. Role of ChemR23 in directing the migration of myeloid and plasmacytoid dendritic cells to lymphoid organs and inflamed skin. J Exp Med 2005;201:509-15.

9. Perumalsamy S, Aqilah Mohd Zin NA, Widodo RT, et al. Chemokine like receptor-1 (CMKLR-1) receptor: A potential therapeutic target in management of chemerin induced type 2 diabetes mellitus and cancer. Curr Pharm Des 2017;23(25):3689-98.

10. Yamawaki $\mathrm{H}$, Kameshima $\mathrm{S}$, Usui $\mathrm{T}$, et al. A novel adipocytokine, chemerin exerts anti-inflammatory roles in human vascular endothelial cells. Biochem Biophys Res Commun 2012;423(1):152-7.

11. Nagpal S, Patel S, Jacobe H, et al. Tazarotene-induced gene 2 (TIG2), a novel retinoid-responsive gene in skin. J Invest Dermatol 1997;109(1):91-5.

12. Goralski KB, McCarthy TC, Hanniman EA, et al. Chemerin, a novel adipokine that regulates adipogenesis and adipocyte metabolism. J Biol Chem 2007;282(38):28175-88.

13. Mattern A, Zellmann T, Beck-Sickinger AG. Processing, signaling, and physiological function of chemerin. IUBMB Life 2014;66(1):19-26.

14. Du X-Y, Leung LLK. Proteolytic regulatory mechanism of chemerin bioactivity. Acta Biochim Biophys Sin (Shanghai) 2009;41(12):973-9.

15. Ernst MC, Sinal CJ. Chemerin: At the crossroads of inflammation and obesity. Trends Endocrinol Metab 2010;21(11):660-7.

16. Blundon HL. Development of vascular smooth muscle cell models for investigating the role of CMKLR1/chemerin signalling in atherosclerosis. (Doctoral dissertation), Halifax, Nova Scotia, Canada, Dalhousie University, 2015.

17. Helfer G, Wu QF. Chemerin: A multifaceted adipokine involved in metabolic disorders. J Endocrinol 2018;238(2):R79-94.

18. Rourke JL, Muruganandan S, Dranse HJ, et al. Gpr1 is an active chemerin receptor influencing glucose homeostasis in obese mice. J Endocrinol 2014;222(2):201-15.

19. Chakaroun $R$, Raschpichler M, Kloting N, et al. Effects of weight loss and exercise on chemerin serum concentrations and adipose tissue expression in human obesity. Metabolism 2012;61(5):706-14.

20. Bozaoglu K, Segal D, Shields KA, et al. Chemerin is associated with metabolic syndrome phenotypes in a Mexican-American population. J Clin Endocrinol Metab 2009;94(8):3085-8.

21. Buechler C, Feder S, Haberl EM, et al. Chemerin isoforms and activity in obesity. Int J Mol Sci 2019;20(5):1128.

22. Southern C, Cook JM, Neetoo-Isseljee Z, et al. Screening beta-arrestin recruitment for the identifcation of natural ligands for orphan G-protein-coupled receptors. J Biomol Screen 2013;18(5):599-609.

23. Zabel BA, Nakae oS, Zuniga L, et al. Mast cell-expressed orphan receptor CCRL2 binds chemerin and is required for optimal induction of IgE-mediated passive cutaneous anaphylaxis. J Exp Med 2008;205(10):2207-20.

24. Bondue B, Wittamer V, Parmentier M. Chemerin and its receptors in leukocyte trafficking, inflammation and metabolism. Cytokine Growth Factor Rev 2011;22(5-6):3318.

25. De Henau O, Degroot GN, Imbault $V$, et al. Signaling properties of chemerin receptors CMKLR1, GPR1 and CCRL2. PLoS One 2016;11(10):e0164179.

26. Issa ME, Muruganandan S, Ernst MC, et al. Chemokine-like receptor 1 regulates skeletal muscle cell myogenesis. Am J Physiol Cell Physiol 2012;302(11):C1621-31.

27. Weigert J, Obermeier F, Neumeier M, et al. Circulating levels of chemerin and adiponectin are higher in ulcerative colitis and chemerin is elevated in Crohn's disease. Inflamm Bowel Dis 2010;16(4):630-7.

28. Wittamer V, Bondue B, Guillabert A, et al. Neutrophilmediated maturation of chemerin: A link between ınnate and adaptive immunity. J Immunol 2005;175:487-93.

29. Graham KL, Zabel BA, Loghavi S, et al. Chemokine-like receptor-1 expression by central nervous system-infiltrating leukocytes and involvement in a model of autoimmune demyelinating disease. J Immunol 2009;183(10):6717-23.

30. Bondue B, Vosters O, De Nadai P, et al. ChemR23 dampens lung inflammation and enhances anti-viral immunity in a mouse model of acute viral pneumonia1. PLOS Pathogens 2011;7:e1002358

31. Demoor T, Bracke KR, Dupont LL, et al. The role of ChemR23 in the induction and resolution of cigarette smoke-induced inflammation. J Immunol 2011;186:5457-67.

32. Cash JL, Hart R, Russ A, et al. Synthetic chemerin-derived peptides suppress inflammation through ChemR23. J Exp Med 2008;205(4):767-75.

33. Parlee SD, Ernst MC, Muruganandan S, et al. Serum chemerin levels vary with time of day and are modified by obesity and tumor necrosis factor-\{alpha\}. Endocrinology 2010;151(6):2590-602.

34. Aydın K, Canpolat U, Akın Ş, et al. Chemerin is not associated with subclinical atherosclerosis markers in prediabetes and diabetes. Anatol J Cardiol 2016;16(10):749-55.

35. Mirmajidi S, Izadi A, Saghafi-Asl M, et al. Inflammatory potential of diet: Association with chemerin, omentin, lipopolysaccharide- binding protein, and insulin resistance in the apparently healthy obese. J Am Coll Nutr 2019;38(4):30210.

36. Nakamura N, Naruse K, Kobayashi $\mathrm{Y}$, et al. Chemerin promotes angiogenesis in vivo. Physiol Rep 2018(24):e13962.

37. Sell H, Laurencikiene J, Taube A, et al. Chemerin is a novel adipocyte-derived factor inducing insulin resistance in primary human skeletal muscle cells. Diabetes 2009;58(12):2731-40.

38. Bauer S, Bala M, Kopp A, et al. Adipocyte chemerin release is induced byoinsulin without being translated to higher levels in vivo. Eur J Clin Investig 2012;42:1213-20.

39. Bobbert T, Schwarz F, Fischer-Rosinsky A, et al. Chemerin and prediction of diabetes mellitus type 2. Clin Endocrinol 
(Oxf) 2015;82(6):838-43.

40. Habib SS, Eshki A, Al Tassan Revie B, et al. Relationship of serum novel adipokine chemerin levels with body composition, insulin resistance, dyslipidemia and diabesity in Saudi women. Eur RevwMed Pharmacol Sci 2017;21(6):1296-302.

41. Eckel RH, Grundy SM, Zimmet PZ. The metabolic syndrome. Lancet 2005;365(9468):1415-28.

42. Niklowitz $P$, Rothermel J, Lass $N$, et al. Link between chemerin, central obesity, and parameters of the Metabolic Syndrome: Findings from a longitudinal study in obese children participating in a lifestyle intervention. Int $\mathrm{J}$ Obes (Lond) 2018;42(10):1743-52.

43. Gu P, Jiang $W$, Lu B, et al. Chemerin is associated with inflammatory markers and metabolic syndrome phenotypes in hypertensionnlpatients. Clin Exp Hypertens 2014;36(5):32632.

44. Wang D, Yuan GY, Wang XZ, et al. Plasma chemerin level in metabolic syndrome. Genet Mol Res. 2013;12(4):59-91.

45. Jacewicz-Święcka M, Kowalska I. Polycystic ovary syndrome and the risk of cardiometabolic complications in longitudinal studies. Diabetes Metab Res Rev 2018;34(8):e3054.

46. Kakoly NS, Khomami MB, Joham AE, et al. Ethnicity, obesity and the prevalence of impaired glucose tolerance and type 2 diabetes in PCOS: A systematic review and meta-regression. Hum Reprod Update 2018;24(4):455-67.
47. Aydoğdu A, Haymana C, Tapan S, et al. Polikistik over sendromu olgularında artmış visseral adipozite indeksi; Inflamasyon, insülin direnci ve hiperandrojenite arasındaki ilişki. Gülhane Tıp Derg 2015;57(2):107-10.

48. Brutocao C, Zaiem F, Alsawas M, et al. Psychiatric disorders in women with polycystic ovary syndrome: A systematic review and meta-analysis. Endocrine 2018;62(2):318-25.

49. Lim SS, Hutchison SK, Van Ryswyk E, et al. Lifestyle changes in women with polycystic ovary syndrome. Cochrane Database Syst Rev 2019 28;3:CD007506.

50. Guzel EC, Celik C, Abali R, et al. Omentin and chemerin andtheir association with obesity in women with polycystic ovary syn drome. Gynecol Endocrinol 2014;30(6):419-22.

51. Foda AA, Foda EA, El-Negeri MA, et al. Serum chemerin levels in polycystic ovary syndrome after metformin therapy. Diabetes Metab Syndr 2019;13(2):1309-15.

52. Kort DH, Kostolias A, Sullivan C, et al. Chemerin as a marker of body fat and insulin resistance in women with polycystic ovary syndrome. Gynecol Endocrinol 2015;31(2):152-5.

53. Wang $Y$, Huang $R$, Li X, et al. High concentration of chemerin caused by ovarian hyperandrogenism may lead to poor IVF outcome in polycystic ovary syndrome: A pilot study. Gynecol Endocrinol 2019;35(12):1072-7. 